\title{
Variation in the depth and morphology of burrows of the mud crab Helice crassa among different types of intertidal sediment in New Zealand
}

\author{
D. J. Morrisey ${ }^{1, *}$, T. H. DeWitt ${ }^{2, * *}$, D. S. Roper ${ }^{1, * * *}$, R. B. Williamson ${ }^{1}$ \\ 'National Institute for Water and Atmospheric Research, PO Box 11-115, Hamilton, New Zealand \\ ${ }^{2}$ Battelle Marine Sciences Laboratory, Sequim, Washington 98382, USA.
}

\begin{abstract}
Crabs are among the larger and more active burrowers in intertidal sediments in New Zealand, as in many other parts of the world. Abundances of mud crabs Helice crassa and their burrows were compared among sites differing in the nature of their sediments. Differences in burrow architecture among sites were quantified using casts of burrows made in situ. The effects of bioturbation on sediment geochemistry were also determined with respect to redox potential and the concentrations of 2 chemical phases, acid volatile sulphides (AVS) and iron pyrites ( $\mathrm{FeS}_{2}$ ), that influence the bioavailability of heavy metals. The objective of this study was to identify effects of differences in the extent and nature of burrowing activity of the crab $\mathrm{H}$. crassa among different sediment types on sediment geochemistry, particularly with respect to the bioavailability of heavy metals. Burrows were more abundant at muddy sites (average 22 to 59 burrows $20 \mathrm{~cm}$ diameter core ${ }^{-1}$ ) than at sandy sites (average 12 burrows core ${ }^{-1}$ ). Although not necessarily deeper at muddy sites, burrows were more complex in structure. Average volumes of casts were larger at muddy than sandy sites by a factor of up to 14.8 and at the most densely-burrowed site, burrows represented $14 \%$ of the volume of the surrounding sediment. The architecture of the burrows of $H$. crassa is discussed in the context of published models of burrow structure and function for other crustacea. Patterns of differences in chemical variables among sites were not clear cut. Redox profiles generally showed decreases with depth in the sediment and, among the muddy sites, potentials were highest and most variable at the site with greatest burrowing activity. Concentrations of AVS and $\mathrm{FeS}_{2}$ were lower in sandy sediments than in muddy ones. Among muddy sites, the concentration of AVS was lowest at the site with the greatest amount of burrowing, consistent with introduction of oxygen to the sediment and the consequent oxidation of AVS. Concentrations of $\mathrm{FeS}_{2}$ showed a pattern that suggested that burrowing introduces $\mathrm{FeS}_{2}$ from deeper layers, where concentrations are higher, into shallower, bioturbated layers of the sediment, offsetting effects of oxidation due to burrowing activity. Concentrations of $\mathrm{FeS}_{2}$ were highest at the site with most burrowing activity.

KEY WORDS: Crab·Burrow Bioturbation - Geochemistry $\cdot$ Sediment
\end{abstract}

\section{INTRODUCTION}

Crabs are among the larger and more active burrowers in intertidal soft sediments. Consequences of this

•E-mail: d.morrisey@niwa.cri.nz

Present addresses:

- U.S. Environmental Protection Agency, NHEERL Western Ecology Division, Newport, Oregon 97365, USA

...Electricity Corporation of New Zealand Ltd, PO Box 445, Hamilton, New Zealand burrowing and bioturbation include increased vertical and horizontal movement of sediment and detritus (Rhoads \& Boyer 1982, Takeda \& Kurihara 1987a, Meadows \& Meadows 1991), increased permeability of the sediment to water and air (Ridd 1996), stimulation of microbial activity (Montague 1981, Aller 1982, Andersen \& Kristensen 1991) and the access of oxygenated water to areas of the substratum below the depth of the normal redox discontinuity layer (Wolfrath 1992). This increases the potential for oxidation of reduced chemical species, 
particularly those formed by sulphur, iron and manganese (Berner \& Westrich 1985). These changes in the sediment environment can, in turn, influence the distribution and bioavailability of anthropogenic contaminants within the sediment (Aller 1978).

Intraspecific variation in burrowing activity has been demonstrated in relation to numerous factors. Bertness \& Miller (1984) found that the depth, volume and turnover of burrows of the fiddler crab Uca pugnax in a saltmarsh decreased with increasing height on the shore, correlating with an increase in the hardness of the substratum and the density of the root mat. At lower levels of the shore, the softness of the sediment restricted the construction of burrows. Female and smaller male crabs were found to be better at burrowing than large males, presumably because the latter's enlarged chelipeds are of limited use in digging. Burrowing activity may also vary seasonally. The density of burrows of Uca tangeri on mudflats in southern Portugal was highest in spring and early summer, whereas the depth of burrowing was greatest in winter (Wolfrath 1992).

The effect of sediment texture on burrowing activity has been investigated by Takeda \& Kurihara (1987b), who suggested that the depth of burrowing of Helice tridens is determined by the depth of the water table below the surface of the substratum and the relative proportion of silt-clay in the sediment. The importance of sediment characteristics has also been emphasised as a determinant of the burrow architecture of thalassinidean shrimps (e.g. Hertweck 1972, Griffis \& Suchanek 1991), the burrows of which have been studied in particular detail (e.g. Griffis \& Suchanek 1991, Nickell \& Atkinson 1995). Burrow structure tends to be simpler in sandier sediments.

The small ( 1 to $2 \mathrm{~cm}$ carapace width), grapsid crab Helice crassa is common on intertidal sediments throughout New Zealand (Jones 1976, McLay 1988) and constructs burrows in a range of sediment types in the high shore and semi-terrestrial habitats (Jones \& Simons 1982). Nye (1977) found that their distribution was concentrated higher up the shore in winter and extended further down shore in summer. Maximal abundances (Jones 1980, Jones \& Simons 1983) and burrow depths (Nye 1977) of H. crassa are found in muddier sediments. Jones \& Simons (1982) suggested that $H$. crassa avoids waterlogged, very soft sediments because its burrows are not stable and it lacks the appropriate morphology and behaviour for depositfeeding in such areas. In muddier sediments, the large abundances (e.g. $462 \mathrm{~m}^{-2}$; Jones \& Simons 1983) and extensive burrowing activity make $H$. crassa a potentially very important component of the ecology of coastal and estuarine sediments. They are likely to influence other species directly or indirectly through their feeding activities and their influence on sediment topography and geochemistry. In this respect, they are likely to be representative of burrowing crabs in other parts of the world (e.g. Knox 1986).

Preliminary observations suggested that the abundance of Helice crassa on intertidal sediments in the north of New Zealand varied among locations with different types of sediment. Furthermore, depth and complexity of burrows also appeared to differ among these locations, consistent with the findings of Nye (1977). Nye reported that, at a study site on the South Island of New Zealand, burrows in sand were usually less than $5 \mathrm{~cm}$ deep but that burrows in mud were deeper To date, however, there have been no quantitative estimates of these differences, despite their potential importance for understanding the processing and fate of sediments, organic material and anthropogenic contaminants in estuarine environments.

We compared abundances of Helice crassa and several variables describing the abundance and structural complexity of its burrows among sites with different types of sediment to test the hypothesis that these variables differ among different types of substratum within the same, limited geographical area. We also measured sediment depth-profiles of redox, AVS and iron pyrites to determine whether differences in burrowing activity of crabs in different types of sediment affect the geochemistry of the sediment, specifically the abundance of 2 chemical phases that influence the bioavailability of heavy metals, acid volatile sulphides (AVS - mainly FeS) and iron pyrites $\left(\mathrm{FeS}_{2}\right)$. The trace metals $\mathrm{Zn}, \mathrm{Cu}, \mathrm{Pb}, \mathrm{Cd}$ and $\mathrm{Ni}$ form insoluble sulphides, limiting their solubility in anoxic sediments (Emerson et al. 1983, Lyons \& Fitzgerald 1983, Davies-Colley et al. 1985). The relationship between metal solubility and AVS is the basis for a widely applied model for acute toxicity in sediments (Ankley et al. 1996), while immobilisation by $\mathrm{FeS}_{2}$ is probably a significant factor limiting heavy metal bioavailability (Morse 1994).

\section{MATERIAL AND METHODS}

Study sites. Five intertidal, estuarine sandflats and mudflats on the east and west coasts of the North Island of New Zealand were sampled during the summer (January to March) of 1996 (locations of sites are given in Table 1). The maximum distance between any 2 sites is ca $160 \mathrm{~km}$. The sites were chosen to provide a range of sediment textures, from sands to very fine muds. Two sites were characterised by sand (WeIcome Bay, WB) or muddy-sand (Big Muddy Creek Muddy Sand Site, BMMS). Three were characterised by muddy sediments (Drury Creek, DC Hellyers Creek, $\mathrm{HC}_{i}$ and Big Muddy Creek Muddy Site, BMM). Sediment characteristics are summarised in Table 1. 
Table 1 Dates of sampling, location and characteristics of study sites. \% mud (by dry weight) shown as range among 4 samples from each site (2 in the case of BMMS); all samples at DC were $99 \%$ mud. VOM: volatile organic matter as percentage of dry weight (mean $\pm \mathrm{SE}, \mathrm{n}=2$ for BMMS and 4 for all other sites)

\begin{tabular}{|c|c|c|c|c|c|c|}
\hline Site & Sediment type & Abbreviation & Date sampled & Latitude, Longitude & $\%$ mud & $\%$ VOM \\
\hline Drury Creek & Mud & DC & Feb 9, 1996 & $37^{\circ} 05^{\prime} \mathrm{S}, 174^{\circ} 54^{\prime} \mathrm{E}$ & 99 & $6.0(0.12)$ \\
\hline Hellyers Creek & Mud & $\mathrm{HC}$ & Feb 15, 1996 & $36^{\circ} 47^{\prime} \mathrm{S}, 174^{\circ} 42^{\prime} \mathrm{E}$ & $82-90$ & $5.5(0.12)$ \\
\hline Big Muddy Mud & Mud & $\mathrm{BMM}$ & Feb 15, 1996 & $36^{\circ} 58^{\prime} \mathrm{S}, 174^{\circ} 37^{\prime} \mathrm{E}$ & $74-81$ & $4.6(0.06)$ \\
\hline Big Muddy Muddy Sand & Muddy sand & BMMS & Feb 14, 1996 & $36^{\circ} 58^{\prime} \mathrm{S}, 174^{\circ} 37^{\prime} \mathrm{E}$ & $37-38$ & $2.9(0.01)$ \\
\hline Welcome Bay & Sand & WB & Feb 7,1996 & $37^{\circ} 44^{\prime} \mathrm{S}, 176^{\circ} 11^{\prime} \mathrm{E}$ & $8-17$ & $1.9(0.27)$ \\
\hline
\end{tabular}

Shore transects. A profile of the shore at each site was measured from the approximate height of spring high tides (MHWS, estimated from the position of the highest strand line) to mean low water (based on predicted time and height of low tide). At locations where MHWS lay within the zone of mangroves (Avicennia marina subsp. australasica) at the top of the shore, the transect was begun as far into the mangroves as it was possible to deploy the levelling equipment. The numbers of crab burrows were counted in $0.1 \mathrm{~m}^{2}$ quadrats at 2 to $5 \mathrm{~m}$ intervals along the transect, 1 quadrat at each point.

Abundance and size distribution of crabs and burrow entrances. At each site, 4 plots $(5 \times 5 \mathrm{~m})$ were laid out in either a square (i.e. $10 \times 10 \mathrm{~m}$ total area) or rectangular (i.e. $5 \times 20 \mathrm{~m}$ total area) pattern. These plots were placed in the area where densities of Helice crassa appeared to be greatest and where local environmental features would not affect the ability of the crabs to burrow (e.g. subsurface layers of rock, mangroves, creeks). The arrangement of the plots depended on the width of the tidal flat relative to these environmental features and the spatial distribution of $H$. crassa burrows. Ten random sampling points were selected within the 4 plots, so that no 2 points were closer than $1.5 \mathrm{~m}$ (to maximise dispersion of samples and to prevent trampling of adjacent points while sampling).

At each sampling point, a core tube $(25 \mathrm{~cm}$ diameter, $40 \mathrm{~cm}$ depth) was pushed into the sediment. The number of burrow entrances within the area of the core was counted and the diameters of up to 40 entrances were measured to the nearest $\mathrm{mm}$. The diameters were measured perpendicular to the slanting entrance path because of the irregular shape of the entrance path. All of the sediment within the core was then excavated, placed in a plastic bag for transport to the laboratory and sieved through a $1 \mathrm{~mm}$ mesh. All macrofauna retained on the sieve was preserved in $70 \%$ isopropyl alcohol. All Helice crassa in the samples were counted and measured (width of carapace). Numbers of other large, burrowing crustacea were also counted.

Depth of burrowing. After the core was removed, 1 side of the hole in the sediment was excavated with a flat trowel to reveal an unsmeared, $25 \mathrm{~cm}$ wide vertical face of the sediment. The vertical distance from the surface of the sediment to the bottom of the deepest burrow thus revealed what was measured as an estimate of the maximum burrow depth. Ten such excavations and measurements were made at each site.

Casts of crab burrows. At each site, 10 plastic core tubes (20 cm diameter, $40 \mathrm{~cm}$ depth) were pushed into the sediment, leaving about $5 \mathrm{~cm}$ of the tube above the sediment. Liquid grout (SikaGrout 215, shrinkagecompensated, cementitious grout, Sika [NZ] Ltd) was poured slowly into the tube, allowing it to fill any burrows present. Tubes were left in place for 2 to $6 \mathrm{~d}$ while the grout hardened. Tubes, sediment and casts were dug out and returned to the laboratory, where the surrounding sediment was washed away from the cast using a jet of water.

For measuring the surface area, the casts were painted with a wettable, non-porous, vinyl paint to prevent absorption of water. The surface area of the burrows within the cast was measured by immersing each cast in salt solution, removing it and allowing it to drip for a standardised period of time, then washing the cast 3 times with nanopure water. The volume of the washing water was made up to a known volume and its conductivity measured. Conductivity measurements were calibrated by immersing objects of known surface area (and painted with the same paint) in a salt solution and washing them in the same way. Volumes of the burrows within each cast were measured by the displacement of water. The maximum depth of burrows within each cast was also measured.

Sediment grain size and organic matter. A sample of surficial sediment was collected from each of the 4 plots at all sites except BMMS, for which samples were collected from 2 of the 4 plots. Proportions of mud by dry weight in the samples were determined by sieving (Buchanan 1984). Volatile organic matter was estimated by loss of weight on ignition at $400^{\circ} \mathrm{C}$.

Sediment chemistry. Redox potential was measured with an Orion platinum electrode combined with a built-in silver/silver chloride reference electrode. Potentials are reported relative to the standard $\mathrm{Ag} / \mathrm{AgCl}$ electrode. The electrode was inserted horizontally 

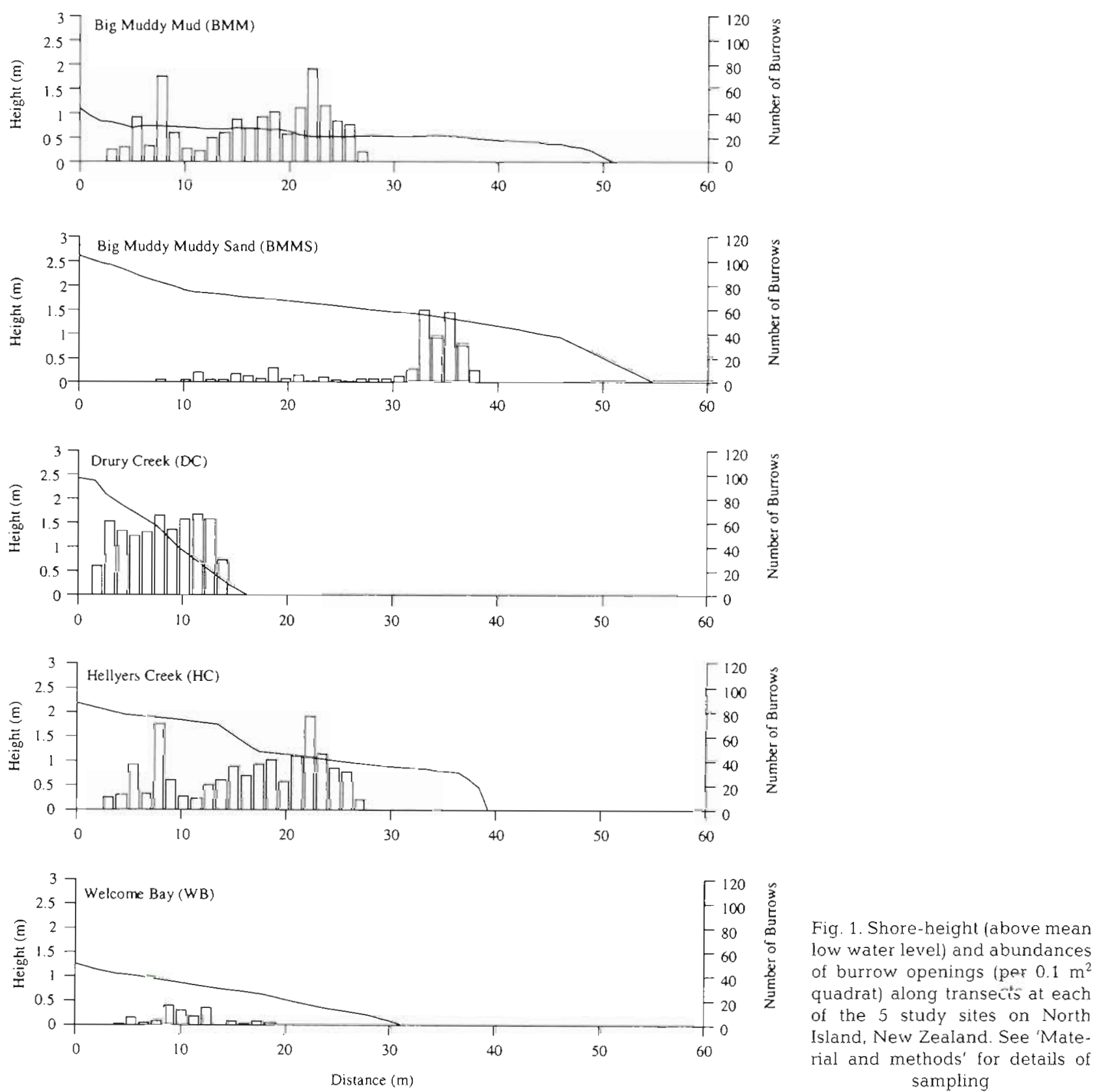

$1 \mathrm{~mm}$ into a freshly uncovered sediment face and the measurement taken within $30 \mathrm{~s}$. Oxygen diffusion to this distance into the sediment is slower than the time needed to take the redox readings (authors' unpubl. data). Initial trials at WB established that the electrode response was rapid (readings after $30 \mathrm{~s}$ were within $5 \%$ of those after $2 \mathrm{~min}$ ) and reproducible (CV ranged from up to $20 \%$ for oxic sediments to less than $5 \%$ for dark grey sediments). The electrolyte solution in the reference electrode was renewed at the start and end of each series of measurements to prevent poisoning of the electrode by sulphide. Measurements were typically made over a $30 \mathrm{~cm}$ wide, 10 to $30 \mathrm{~cm}$ deep profile at depths of $0,2,5,10,15,20$ and $30 \mathrm{~cm}$, the deepest measurement in each profile being taken just below the bottom of the deepest burrow in that profile. Values were plotted using contour-plotting software (Surfer version 6: Golden Software Inc. 1995).

AVS and $\mathrm{FeS}_{2}$ were analysed by a microdiffusion method that uses $6 \mathrm{M} \mathrm{HCl}$ and $10 \% \mathrm{SnCl}_{2}$ to release $\mathrm{H}_{2} \mathrm{~S}$ from AVS in the diffusion process and prevent oxidation by $\mathrm{Fe}^{3+}$, and $6 \mathrm{M} \mathrm{HCl}$ and $1 \mathrm{M} \mathrm{CrCl}_{2}$ to release $\mathrm{H}_{2} \mathrm{~S}$ from $\mathrm{FeS}_{2}$ (Williamson et al. in press). At our sites, most of the AVS is FeS because concentrations of other sulphide-forming heavy metals such as $\mathrm{Zn}, \mathrm{Pb}, \mathrm{Cu}, \mathrm{Cd}$ and $\mathrm{Ni}$ are relatively low (Glasby et al. 1988). 
Statistical methods. The numbers of burrow openings relative to the numbers of crabs in cores from the sampling plots were compared by linear regression, using data from all 5 sites. Comparisons of sizes of crabs and of sizes of burrow openings among the sites were made using Kruskal-Wallis single-factor analyses of variance, with non-parametric multiple comparison tests (Zar 1984, p. 199 et seq.). This non-parametric test was used, rather than a parametric ANOVA, because the size distributions of both crabs and burrow openings were strongly skewed. Average depths of burrows and the volumes, surface areas and the ratio volume: 'depth of the deepest burrow' of the burrow casts were compared among sites using single-factor, parametric ANOVA with Scheffe's multiple comparison procedure. Heterogeneity of variances was tested using Cochran's test and, when variances were heterogeneous, data were square-root transformed. The significance of differences in concentrations of AVS and iron pyrites among sites was tested by comparing $95 \%$ confidence intervals about the site means.

\section{RESULTS}

\section{Abundance and size distribution of crabs and burrow entrances}

Openings of crab burrows were present over much of the intertidal profile but showed a clear maximum towards mean low water (MLW; Fig. 1). Abundances of burrow openings also varied among sites. Maximal abundances were larger for the muddier sites (BMM, $1080.1 \mathrm{~m}^{-2}$; HC, $760.1 \mathrm{~m}^{-2}$; DC, $670.1 \mathrm{~m}^{-2}$, though at the last of these sites the lower $4 \mathrm{~m}$ of the shore was underwater by the time the transect was done and burrows could not be counted), as compared to the sandier sites (BMMS, $600.1 \mathrm{~m}^{-2}$; WB, $160.1 \mathrm{~m}^{-2}$ ). The identity of the species making the burrows was not determined at the time and other potential burrowers were an ocypodid crab Macrophthalmus hirtipes and a snapping shrimp Alpheus sp. Counts of the abundances of these other species (Table 2) showed, however, that Helice crassa was by far the most abundant species and, therefore, likely to be responsible for the large majority of burrows.

Sampling plots were deliberately sited in areas of high abundance of burrows which, as the results of the transects indicates, tended to be towards MLW. Again, abundances of burrow openings were larger on muddier (BMM, DC) than for sandier (WB, BMMS) shores (Table 2). The small average abundance for $\mathrm{HC}$ relative to the maximal value from the transect indicates that the plots were not placed in the area of largest abundance. Additional cores taken lower down the shore (on the shoulder and top of the slope of the creek bank) had a similar mean abundance to the sampling plot $\left(21.8\right.$ core $\left.^{-1} \pm 1.85 \mathrm{SE}_{1} \mathrm{n}=6\right)$. The regression of number of burrow openings on the number of crabs, using data from all 5 sites, indicates that there were considerably more openings than crabs in a given area of substratum (regression equation: number of openings $=1.60[$ number of crabs $]+15.00 ; t_{46}=8.46$, $\left.p<0.0001, r^{2}=0.61\right)$.

Table 2. Numbers and sizes (carapace width) of Helice crassa, numbers of other large, burrowing crustaceans (the crab Macrophthalmus hirtipes and the snapping shrimp Alpheus sp.) and numbers, diameters and maximum depths of burrows in core samples (25 cm diameter, $40 \mathrm{~cm}$ deep). Site abbreviations as in Table 1 . Superscripts indicate results of multiple comparisons for KruskalWallis tests (crab and burrow sizes) or ANOVA (depth of burrows). Sites sharing the same superscripted letter in the same column are not significantly different. See text for details of analyses

\begin{tabular}{|c|c|c|c|c|c|c|}
\hline Site & Sediment type & $\begin{array}{l}\text { Mean no. } \\
\text { H. crassa core } \text { cre }^{-1} \text { (SE) }\end{array}$ & $\begin{array}{c}\text { Mean size } \\
\text { H. crassa }(\mathrm{SE})(\mathrm{mm})\end{array}$ & $\begin{array}{c}\text { Median size } \\
\text { H.crassa }(\mathrm{mm})\end{array}$ & $\begin{array}{c}\text { Mean no. } \\
\text { M. hirtipes core }{ }^{-1}(\mathrm{SE})\end{array}$ & $\begin{array}{c}\text { Mean no. } \\
\text { A. sp. core }{ }^{-1}(\mathrm{SE})\end{array}$ \\
\hline DC & Mud & $27.8(3.55, n=10)$ & $5.7(0.16, \mathrm{n}=278)$ & $5.7^{\mathrm{b}}$ & $O(n=10)$ & $0.2(0.13, \mathrm{n}=10)$ \\
\hline $\mathrm{HC}$ & Mud & $3.8(1.67, n=10)$ & $6.7(0.31, \mathrm{n}=38)$ & $6.9^{a, b}$ & $1.2(0.71, n=10)$ & $0.5(0.31, \mathrm{n}=10)$ \\
\hline BMM & Mud & $13.3(2.53, \mathrm{n}=10)$ & $6.9(0.23, \mathrm{n}=129)$ & $6.6^{\mathrm{a}}$ & $0.7(0.33, n=10)$ & $0.2(0.13, n=10)$ \\
\hline BMMS & Muddy sand & $1.7(0.47, \mathrm{n}=10)$ & $8.7(0.51, n=17)$ & $8.2^{\mathrm{a}}$ & $0.8(0.29, n=10)$ & $0(\mathrm{n}=10)$ \\
\hline WB & Sand & $6.4(0.65, \mathrm{n}=10)$ & $8.3(0.41, \mathrm{n}=61)$ & $8.4^{\mathrm{a}}$ & $0(n=10)$ & $0(n=10)$ \\
\hline Site & Sediment type & $\begin{array}{l}\text { Mean no. holes core }{ }^{-1} \\
\text { (SE) }\end{array}$ & $\begin{array}{l}\text { Mean size holes } \\
(\mathrm{SE})(\mathrm{mm})\end{array}$ & $\begin{array}{l}\text { Median size holes } \\
\text { (mm) }\end{array}$ & $\begin{array}{c}\text { Mean maximum } \\
\text { depth } \operatorname{core}^{-1}(\mathrm{SE})(\mathrm{cm})\end{array}$ & \\
\hline DC & Mud & $58.7(3.46, \mathrm{n}=10)$ & $6.8(0.20, n=400)$ & $6^{a}$ & $25.6(2.19, \mathrm{n}=10)^{1 \mathrm{i}}$ & \\
\hline $\mathrm{HC}$ & Mud & $22.3(4.69, \mathrm{n}=9)$ & $7.8(0.34, n=226)$ & $7^{a}$ & $20.9(1.11, \mathrm{n}=10)^{\mathrm{d}}$ & \\
\hline BMM & Mud & $54.8(7.27, n=9)$ & $7.0(0.23, n=366)$ & $6^{a}$ & $21.3(1.99, \mathrm{n}=10)^{\mathrm{cl}}$ & \\
\hline BMMS & Muddy sand & $12.3(1.27, \mathrm{n}=10)$ & $6.0(0.37, \mathrm{n}=123)$ & $5^{a}$ & $28.6(2.59, \mathrm{n}=10)^{\mathrm{d}}$ & \\
\hline WB & Sand & $12.4(1.78, \mathrm{n}=10)$ & $6.1(0.35, n=120)$ & $5^{a}$ & $9.1(0.76, \mathrm{n}=10)^{\mathrm{b}}$ & \\
\hline
\end{tabular}


There were significant differences among sites in the sizes of crabs (single factor Kruskal-Wallis test statistic $=53.65, \mathrm{df}=4, \mathrm{p}<0.001$ ) and diameters of burrow openings (Kruskal-Wallis test statistic $=10.03, \mathrm{df}=4$, $\mathrm{p}<0.05$ ) (Fig. 2). The actual differences among median values for the different sites were, however, small (5.7 to 8.4 and 5 to $7 \mathrm{~mm}$ for the sizes of crabs and burrows, respectively) relative to the range of sizes (1.0 to 15.4 and 1 to $40 \mathrm{~mm}$, respectively). Multiple comparison tests of differences among sites were inconclusive (Table 2). The distribution of sizes of crabs at each site was not generally skewed but in some cases, particularly DC (which had the largest sample size), appeared to be bimodal (Fig. 3). The distributions of burrow sizes for each site were skewed towards the smaller end of the range (Fig. 4).

Correlations between the size of individual crabs and the size of the burrows in which they were found could not be calculated because appropriate data were not collected. There was no relationship between the median size of crabs and the median size of burrows in plots, when analysed on a site-by-site basis $(n=10$. $\mathrm{p}>0.05$ ) or when plot data were pooled across all sites $(\mathrm{n}=44, \mathrm{r}=0.233, \mathrm{p}>0.05)$.

\section{Depth of burrowing}

Average maximum depths per core (Table 2) ranged from $29 \mathrm{~cm}$ at BMMS (muddy sand) to $9 \mathrm{~cm}$ at $\mathrm{WB}$ (sand). The maximum depths of burrows were not different among sites with mud (BMM, DC, HC) or muddy sand (BMMS), but the depths at all of these sites were larger than at the sandy site (WB) (Table 2 , $F_{4,44}=14.73, \mathrm{p}<0.0001$, results of multiple comparisons are shown in Table 2).
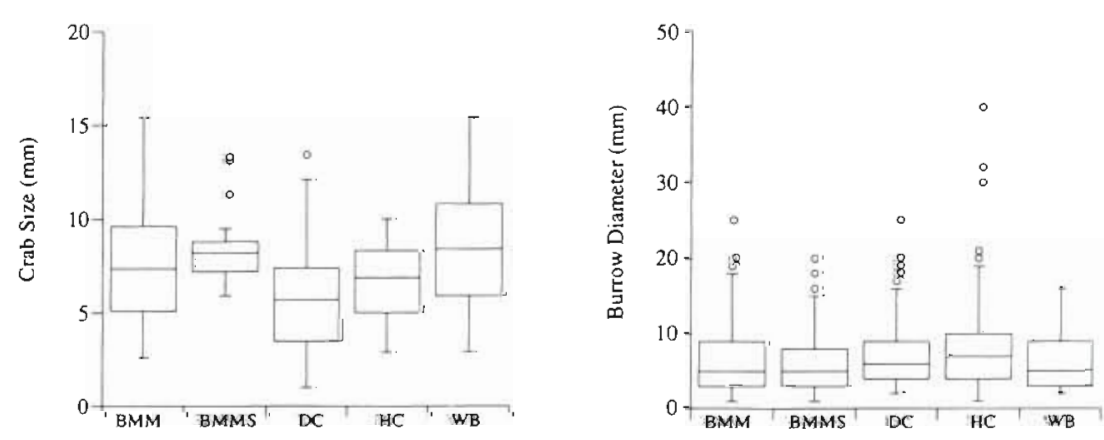

Fig. 2. Helice crassa. Box and whisker plots of burrow diameter and crab size (width of carapace) at each of the 5 study sites. Boxes show median, 25 th and 75 th percentiles. Whiskers show $1.5 \times$ inter-quartile range from the box and points lying outside this range are also shown

\section{Casts of crab burrows}

The complexity of the burrows contained within the casts varied considerably among sites. At the sandiest site, WB, burrows consisted of a single, simple shaft up to $10 \mathrm{~cm}$ deep. At the muddier sites, burrows were deeper (Table 3 ) and much more complex in structure, with multiple vertical shafts within each cast, interconnected by horizontal tunnels. Burrows at BMMS were as deep as those at muddier sites but less complex in structure.

For all sites, the average depth of the deepest burrow in casts was less than the average maximum depth measured at the same site in the field (see above). This indicated that the grout used in the casts had not completely penetrated burrows, particularly the deeper, more complicated ones. The difference in depth between field and cast data for BMM, BMMS and $\mathrm{HC}$ was a factor of 2 or more. Penetration of the burrows at DC and WB was better, with a ratio of 1.6 and 1.4 (field:cast), respectively.

These differences in complexity are reflected in the relative total volumes and surface areas of burrows in casts from different sites (Table 3 ). In the case of burrow volume, the mean for DC (mud) was larger than BMM (mud) and HC (mud) which, in turn, were larger than WB (sand) and BMMS (muddy sand) (Table 3; $F_{4,43}=60.22, \mathrm{p}<0.0001$ for square-root transformed data). Mean burrow volumes differed by a factor of almost 15 between the largest (DC) and smallest (WB) values. The mean surface area of burrows at DC was larger than at all the other sites (Table $3 ; F_{4,43}=24.26$, $\mathrm{p}<0.0001$ for untransformed data, note that variances were heterogeneous after square-root and log transformation). The largest value (DC) was 3.6 times larger than the smallest (WB). The fact that grout probably did not penetrate burrows completely means that values for surface area and volume of burrows are likely to be underestimates. They do, however, provide measures of relative differences among sites and types of substratum.

Burrow volume:depth of deepest burrow for each cast was used as a measure of relative complexity of burrow architecture among sites (Table 3). If the differences in volume and surface area of burrows among sites was simply due to the fact that burrows were deeper at some sites, this ratio would remain similar among sites. If the abundance and complexity of burrows differ among sites, however, this ratio will also differ. 


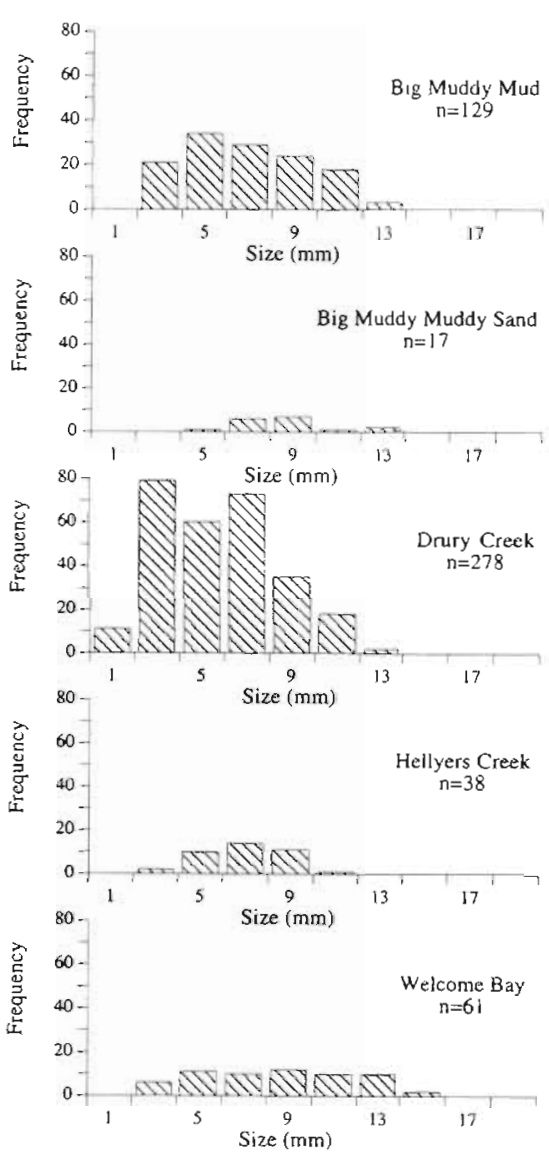

Fig. 3. Helice crassa. Size class composition of mud crabs sampled in cores from each site. Numbers on $x$-axis show midpoint of each size class. See 'Material and methods' for details of sampling

There were differences among sites in the value of this ratio (Table $3 ; F_{4.43}=19.94, \mathrm{p}<0.0001$ ). The largest values (most complex burrows) were found at $\mathrm{DC}, \mathrm{BMM}$ and $\mathrm{HC}$ (in descending order, though differences were not statistically significant, as shown by the multiple comparisons in Table 3). Values for WB and BMMS were similar and much smaller than for the other sites.

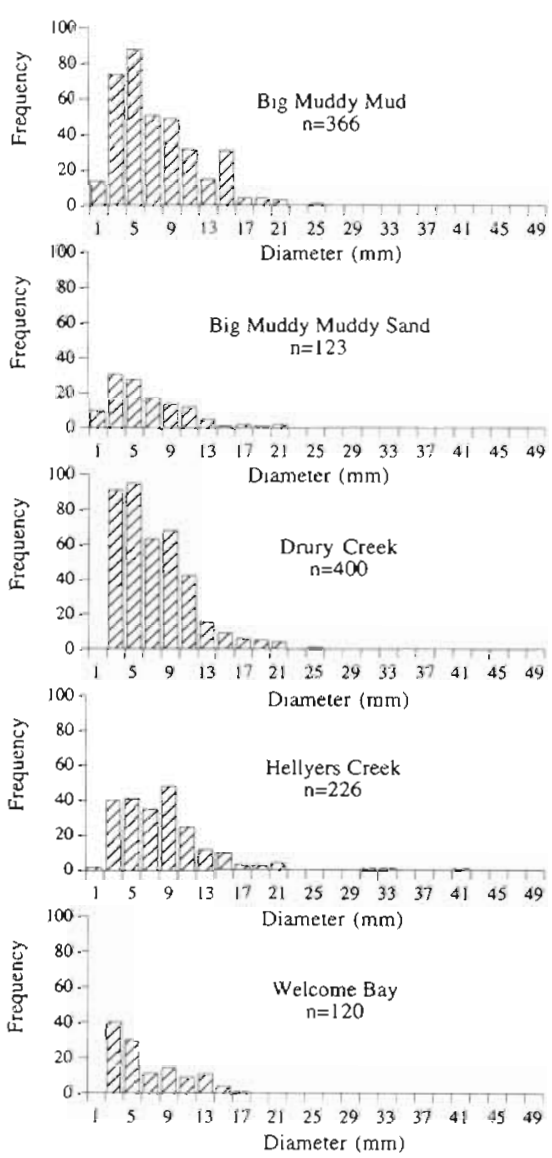

Fig. 4. Size class composition of burrow openings sampled in cores from each site. Numbers on $x$-axis show midpoint of each size class. See text for details of sampling

\section{Sediment chemical profiles}

Redox potentials did not always show a steady decrease with depth, and there was variability among sites (Fig. 5). Of the 3 muddy sites, DC showed the largest variability and also showed the smallest decrease in redox potential with depth $(-260 \mathrm{mV}$, $-500 \mathrm{mV}$ and $-450 \mathrm{mV}$ maximum values for $\mathrm{DC}$, HC and $B M M$, respectively).

Table 3. Characteristics of burrows measured from casts - see 'Results' for details. Site abbreviations as in Table 1. (SA) surface area, (vol) volume. Superscripts indicate results of multiple comparisons for ANOVA. Sites sharing the same superscripted letter in the same column are not significantly different. See 'Results' for details of analyses

\begin{tabular}{|c|c|c|c|c|c|c|}
\hline Site & $\begin{array}{l}\text { Mean burrow vol } \\
\text { (SE) (ml) }\end{array}$ & $\begin{array}{l}\text { Mean burrow SA } \\
\text { (SE) }\left(\mathrm{cm}^{2}\right)\end{array}$ & $\begin{array}{l}\text { Mean depth of } \\
\text { cast }(\mathrm{SE})(\mathrm{cm})\end{array}$ & $\begin{array}{l}\text { Mean vol:depth } \\
\text { (SE) }\end{array}$ & $\begin{array}{c}\text { Mean burrow } \\
\text { SA:sediment SA (SE) }\end{array}$ & $\begin{array}{c}\text { Mean burrow } \\
\text { vol as \% of cast vol (SE) }\end{array}$ \\
\hline DC & $695.5(69.88, n=11)^{a}$ & $4258.8(471.13, \mathrm{n}=11)^{\mathrm{b}}$ & $16.2(1.26, n=11)$ & $43.9(4.20, \mathrm{n}=11)^{\mathrm{a}}$ & $13.6(1.50, n=11)$ & $14.0(1.34, \mathrm{n}=11)$ \\
\hline BMM & $323.9(41.70, n=10)^{b}$ & $2148.9(213.52, n=10)^{d}$ & $10.8(0.42, n=10)$ & $30.2(3.76, \mathrm{n}=10)^{\mathrm{a}}$ & $6.8(0.68, \mathrm{n}=10)$ & $9.6(1.20, n=10)$ \\
\hline $\mathrm{HC}$ & $267.4(28.52, n=9)^{b}$ & $1495.9(96.22, \mathrm{n}=9)^{\mathrm{a}}$ & $10.3(1.77, \mathrm{n}=9)$ & $29.8(4.42, \mathrm{n}=9)^{d}$ & $4.8(0.31, n=9)$ & $9.5(1.41, n=9)$ \\
\hline BMMS & $50.5(17.74, n=10)^{c}$ & $1293.7(50.17, \mathrm{n}=10)^{\mathrm{a}}$ & $10.5(4.81, n=10)$ & $8.5(2.38, n=10)^{b}$ & $4.1(0.16, n=10)$ & $2.7(0.76, n=10)$ \\
\hline WB & $47.2(7.25, n=8)^{c}$ & $1179.9(98.83, \mathrm{n}=8)^{\mathrm{a}}$ & $6.4(0.60, n=10)$ & $7.4(0.95, n=8)^{6}$ & $3.8(0.31, n=8)$ & $2.4(0.30, n=8)$ \\
\hline
\end{tabular}



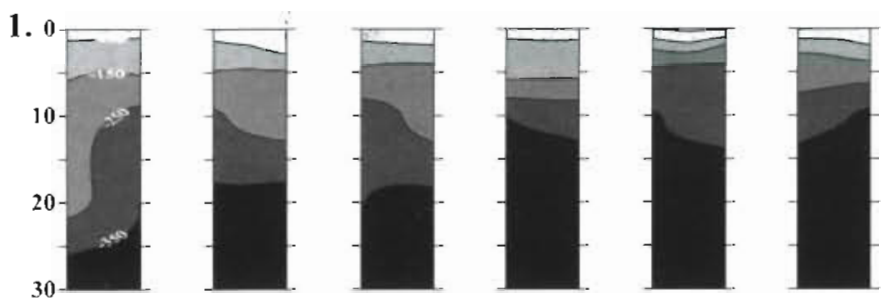

2. 0
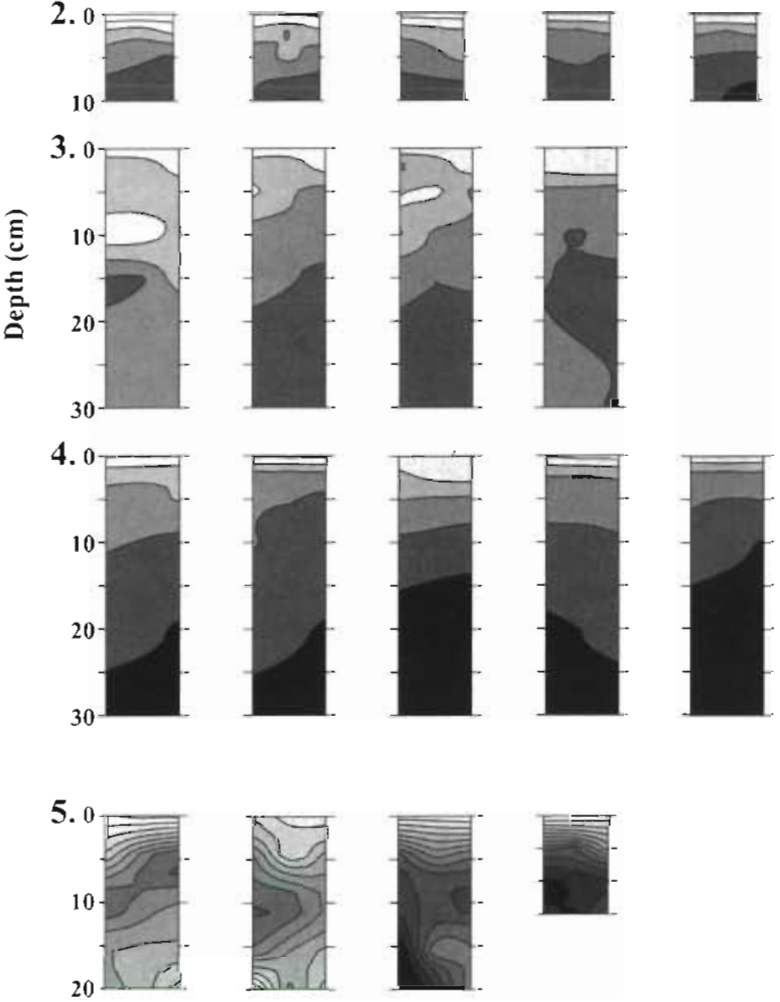

Fig. 5. Redox profiles of freshly exposed, vertical sediment faces ( 4 to 6 profiles at each study site). Potentials (mV) are relative to $\mathrm{AgCl}$ reference electrode. Sites: (1) BMM, (2) BMMS, (3) DC, (4) HC, (5) WB. See 'Material and methods' for details of sampling

AVS and $\mathrm{FeS}_{2}$ concentrations varied among sites and with depth (Fig. 6: variation in concentrations with depth were not measured at BMMS due to an error in labelling of samples). Concentrations were significantly lower (non-overlapping 95\% CI) at WB (sand) than at all other sites (Table 4, Fig. 6). BMM and BMMS had similar mean concentrations, despite differences in degree of burrowing and sediment texture. Of the 3 muddy sites, DC contained the lowest concentrations of AVS but not of $\mathrm{FeS}_{2}$ (Fig. 6).

\section{DISCUSSION}

There are considerable differences in the depth and complexity of the burrows constructed by Helice crassa in different types of sediment and, as a consequence, the total volume of burrows and surface area of burrow walls per unit area of sediment surface also varies considerably. For example, the difference in average volume among different sites was nearly 15 -fold and the equivalent value for area of burrow wall was 3.6. The ratio of area of burrow wall:surface area of sediment in a core $\left(314 \mathrm{~cm}^{2}\right)$ ranged from 3.8 (mean of 8 cores, $\pm 0.31 \mathrm{SE}$ ) for WB (sand) to 13.6 (mean of 11 cores, $\pm 1.5 \mathrm{SE}$ ) for DC (mud) (Table 3). Similarly, the percentage of the total volume of a cast that was occupied by burrow (averaged across all cores from a site) ranged from $2.4 \%( \pm 0.3 \mathrm{SE})$ at $\mathrm{WB}$ to $14.0 \%$ $( \pm 1.3 \mathrm{SE})$ at DC (Table 3). Davey (1994) suggested that ratios between 3.6 and 5.0 represented reasonable estimates of the relative areas of burrow surface and the surface of the overlying sediment. This was based on a review of published studies of the burrows of diverse benthic taxa and his own study of the polychaete Nereis diversicolor. Much larger values (e.g. 1000) have been reported, but Davey suggested that these are overestimates and are physically impossible. The range of values found in the present study is larger than Davey's reported range, but much less than the extreme values he cited.

Maximal abundances of burrow openings occurred in the mid-lower part of the shore. The positive relationship found between numbers of burrows and numbers of crabs in the study plots in the present study suggests that this pattern also applies to the distribution of the crabs themselves. Other studies (Beer 1959. Jones 1976, Nye 1977) have reported finding maximal abundances of crabs in the upper shore. Nye (1977), however, observed that the distribution spread further down shore in summer. That the present study was done in summer while those of Beer (1959) and Jones (1976) were done in late summer-spring and winter, respectively, may account for this difference.

The range of abundance of Helice crassa among the sites in the present study $\left(35 \mathrm{~m}^{-2}\right.$ at a muddy sand site, BMMS to $570 \mathrm{~m}^{-2}$ at a muddy site, $\mathrm{DC}$ ) is similar to that

Table 4. Concentrations of AVS and $\mathrm{FeS}_{2}$ in sediments at each of the study sites, averaged across all depths sampled $(0,2,5$, $10 \mathrm{~cm}$ and just below the deepest burrow in each sediment face). Total sample sizes: 20 for BMM and DC, 19 for BMMS, 24 for $\mathrm{HC}$ and 25 for WB

\begin{tabular}{|lccc|}
\hline Site & $\begin{array}{c}\text { Sediment } \\
\text { type }\end{array}$ & $\begin{array}{c}\text { AVS }(95 \% \mathrm{CI}) \\
\left(\mu \mathrm{mol} \mathrm{g} \mathrm{g}^{-1} \mathrm{dry} \text { wt) }\right.\end{array}$ & $\begin{array}{c}\mathrm{FeS}_{2}(95 \% \mathrm{CI}) \\
\left(\mu \mathrm{mol} \mathrm{g}{ }^{-1} \text { dry wt }\right)\end{array}$ \\
\hline DC & Mud & $10.9(6.4-15.4)$ & $32.4(18.2-46.6)$ \\
HC & Mud & $23.3(14.6-32.0)$ & $26.6(17.6-35.6)$ \\
BMM & Mud & $17.3(10.6-24.0)$ & $48.6(36.0-61.4)$ \\
BMMS & Muddy sand & $17.1(12.7-21.5)$ & $47.3(30.0-64.6)$ \\
WB & Sand & $3.9(2.9-5.0)$ & $16.1(11.7-20.5)$ \\
\hline
\end{tabular}



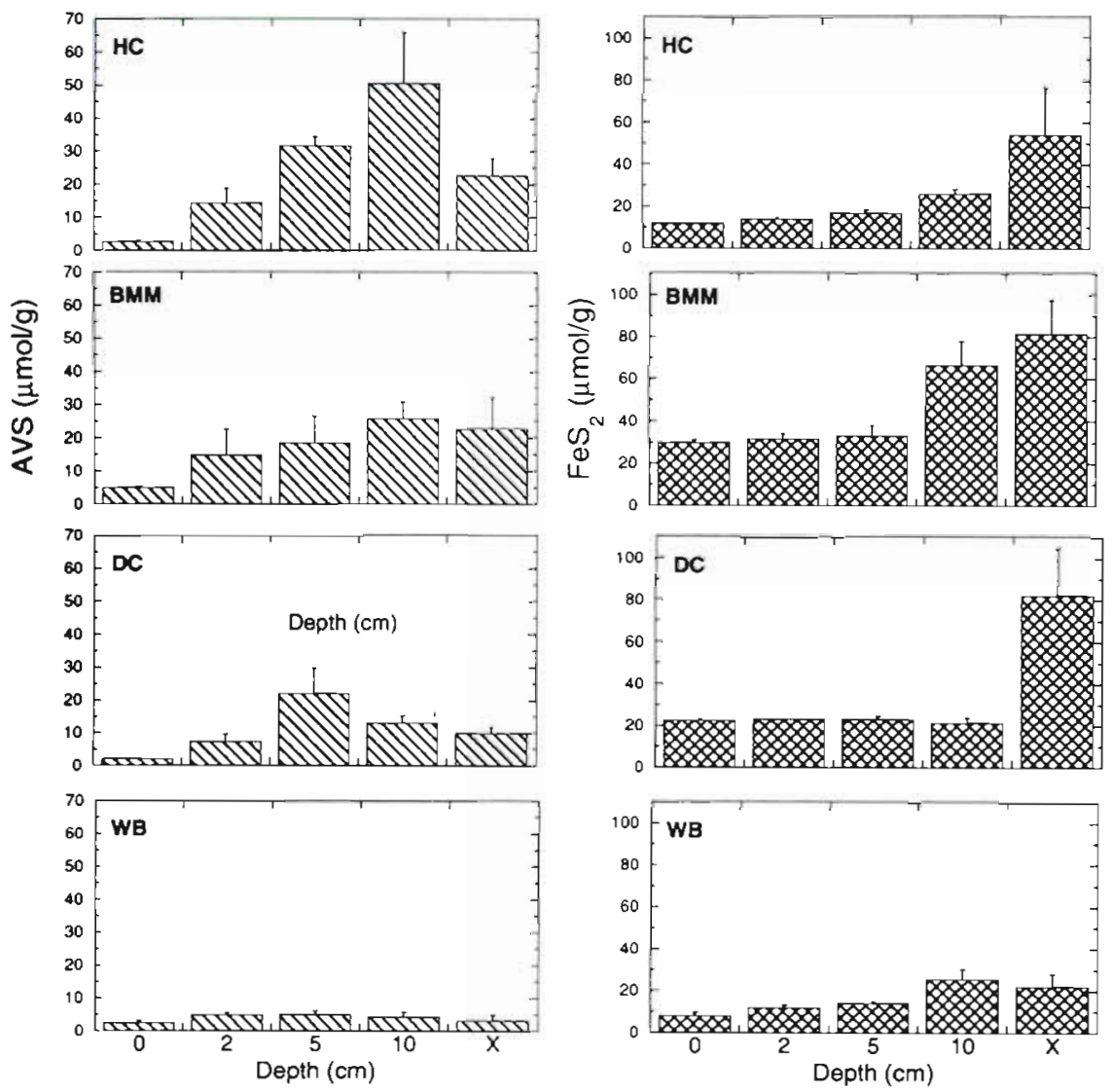

Fig. 6. Vertical profiles of concentrations of acid volatile sulphides (AVS) and $\mathrm{FeS}_{2}$ on freshly exposed, vertical sediment faces (mean for each site $+\mathrm{SE}, \mathrm{n}=6$ for BMM, 4 for $D C$ and $W B$, and 5 for $H C$ ). $X$ : measurement taken just below deepest burrow on each profile. No data for BMMS

reported by Jones \& Simons (1983: 39 to $462 \mathrm{~m}^{-2}$ ) at sites throughout New Zealand and with a range of types of substratum. Abundances of $H$. crassa are generally greater at sites with muddier substrata compared to those with sandier substrata (Jones $\&$ Simons 1983, present study). There were more burrow openings than crabs in a given area, consistent with the results of a study of fiddler crabs Uca rapax in a Florida saltmarsh (Genoni 1991). The ratio of numbers of $U$. rapax:numbers of burrows was 0.74 , and crabs dug new burrows even when unoccupied burrows were available.

Not only were crabs and their burrows more abundant in muddier sediments, but the structure of the burrows was more complex (though not necessarily deeper; Table 3). Nye (1977) found that burrows were usually shallower than $5 \mathrm{~cm}$ in sandy sediments but deeper in muddy areas within the same shore. The findings of the present study generally confirm this observation although at BMMS (muddy sand) the burrows were as deep as at the muddy sites, but less complex. Burrows of the congeneric Helice tridens were smaller, shallower and less abundant in sediments that were sandier and had relatively high water contents (Takeda \& Kurihara 1987b).

Several researchers have quantified the effects of bioturbation by macrofauna on the structure, microbial activity and geochemistry of sediments (e.g. Aller 1978, Katz 1980, Takeda \& Kurihara 1987a, Meadows \& Tait 1989, Wolfrath 1992, Pelegrí \& Blackburn 1994, Forster \& Graf 1995, Gilbert et al. 1995, Mayer et al. 1995). The observed variation in burrow volume and surface area among different types of sediment is, therefore, likely to give rise to differences in these processes. Burrowing will introduce relatively oxygen-rich water below the normal depth of the redox discontinuity layer of finer, organic-rich sediments. In sediments contaminated with heavy metals, this will potentially increase the bioavailability of the contaminants through the oxidation of metal-binding sulphides. This was demonstrated in freshwater sediments spiked with cadmium and zinc (Peterson et al. 1996). Bioturbation by the oligochaete Lumbriculus variegatus reduced AVS concentrations and increased the concentration of $\mathrm{Cd}$ in interstitial water and its rate of biological uptake. There was, however, no measurable effect on zinc availability or uptake. Although the diffusion of oxygen from burrows into the surrounding sediment may be limited, mobilisation of contaminants in the immediate environment of the burrowing organism may potentially increase its exposure.

Burrowing introduces oxygen into reduced sediments, which oxidises iron sulphides $\left(\mathrm{FeS}, \mathrm{FeS}_{2}\right)$ and reduced ions that influence redox potential, such as $\mathrm{Fe}^{2+}$. Concentrations of AVS and FeS and, to a lesser extent, redox potentials depend, however, upon a number of other processes besides bioturbation. Consequently, differences in distributions of these phases among sites cannot be attributed simply to effects of burrowing. For example, concentrations of AVS and $\mathrm{FeS}_{2}$ decrease with the proportion of sand in the sediment (Williamson et al. 1994). It is uncertain to what extent particle size affects redox potential, although it is known to have a strong effect on the concentrations of dissolved ions (e.g. $\mathrm{Fe}^{2+}$ ) that influence redox potential (Williamson et al. 1994). In addition to effects of particle size, AVS is lost through conversion to $\mathrm{FeS}_{2}$ at 
depth in the sediment (Williamson et al. in press). Consequently, it is usual for concentrations of AVS in sediment profiles to peak near the bottom of the bioturbated layer and for concentrations of $\mathrm{FeS}_{2}$ to increase with depth. This general pattern was observed at all the sites in the present study. Concentrations of $\mathrm{FeS}_{2}$ do not decrease markedly in the surface layer, as those of AVS do, because oxidation of $\mathrm{FeS}_{2}$ is slower than that of AVS.

Redox potentials generally decrease down sediment profiles, with the increase in reducing conditions, and this pattern was seen in the profiles in the present study. We made no attempt to measure redox potentials around burrows systematically, but the redox patterns seen appeared to reflect the random occurrence of burrows. The greater variability and higher redox potential observed at $D C$, relative to the 2 other muddy sites, are consistent with the greater degree of bioturbation at that site. The strong redox anomalies found at the sandy site (WB) (Fig. 6) may reflect a more pronounced influence of oxygen from burrows. Concentrations of reduced compounds (AVS and $\mathrm{FeS}_{2}$ ) were much lower at this site (Fig. 6, Table 4), and the permeability of the sandier sediment is likely to be relatively high, allowing oxygen to penetrate deeper into the sediment surrounding burrows. BMM (muddy) and BMMS (muddy sand) had similar redox potentials in the top $10 \mathrm{~cm}$ and similar concentrations of AVS and $\mathrm{FeS}_{2}$. This suggests that although concentrations of these phases were expected to be lower at the sandier site (BMMS), this may have been counter-balanced by less bioturbation and, hence, less oxidation. Of the 3 muddy sites, AVS concentrations were lowest at DC, which is consistent with the greater amount of burrowing activity observed in the sediments at that site (Fig. 6, Table 3).

Concentrations of $\mathrm{FeS}_{2}$ were no lower at DC than at the other muddy sites, again consistent with the greater burrowing activity. Bioturbation has 2 counteracting effects on the concentration of $\mathrm{FeS}_{2}$. It introduces oxygen to the sediment, causing oxidation of $\mathrm{FeS}_{2}$, but it also increases the supply of $\mathrm{FeS}_{2}$ to the bioturbated layer as crabs excavate new burrows in reduced sediment containing high concentrations of $\mathrm{FeS}_{2}$. The results of these excavations can be seen as black sediment deposited around the mouths of some burrows (authors' pers. obs.). Consequently, concentrations of $\mathrm{FeS}_{2}$ tend to be reasonably consistent throughout the bioturbated layer but increase sharply below it (Fig. 6). At DC, concentrations of $\mathrm{FeS}_{2}$ were very uniform throughout the bioturbated layer and concentrations at the sediment surface were higher than at any other site (Fig. 6). This is consistent with greater translocation of $\mathrm{FeS}_{2}$ from deeper in the sediment by the burrowing activity of crabs and with the greater mixing of the bioturbated layer.
The present study confirms that burrowing reduces concentrations of AVS in sediments, which has important consequences for the bioavailability of trace metals. The effect on concentration of $\mathrm{FeS}_{2}$ is different because any increase in oxidation of this phase is counter-balanced by increased translocation of material from lower layers of the sediment. As a result, the proportion of trace metals that are associated with $\mathrm{FeS}_{2}$ and, hence, rendered relatively immobile does not change with the degree of crab burrowing. We reiterate, however, that effects of burrowing on sediment geochemistry can be less important than other factors such as differences in sediment texture.

Various researchers (for reviews, see Griffis \& Suchanek 1991, Nickell \& Atkinson 1995) have proposed that the feeding habits of different species of thalassinidean shrimps are an important factor in determining interspecific differences in burrow architecture. Nickell \& Atkinson (1995) developed a model incorporating a set of burrow features considered to be 'indicators of certain trophic requirements or modes'. These individual components are incorporated into the overall structure of a particular burrow in combinations appropriate to local environmental factors that determine, among other things, the predominant trophic mode, and to the anatomy of the particular species. These individual features of the burrow are equated to potential functions (e.g. feeding, construction and maintenance of the burrow, emergence to collect food or remove waste), sources of nutrition and, thereby, trophic mode.

A number of features in the model of Nickell \& Atkinson (1995) can be identified in the burrow architecture of Helice crassa, namely the presence of oblique tunnels from the surface of the substratum, several openings from the same system of burrows, and funnel-shaped entrances to the burrows. These particular features are interpreted in the model as indicators of the importance of access to the surface and, in turn, of deposit-feeding on surficial, organic material. This mode of feeding fits observations of $H$. crassa by Beer (1959), who described the species as feeding by picking up small amounts of surficial sediment with the tips of the chelae and transferring it to the mouthparts. Observations of meiofaunal and macrofaunal organism in the gut of this species (NIWA unpubl. data) suggest, however, that it does not feed solely on detritus. As with many deposit-feeding species (see, for example, Morrisey 1987), there is probably a substantial opportunistic component of the diet of H. crassa (Beer 1959).

In the case of species, such as Helice crassa, that are active outside their burrows for much of the time, the importance of the burrow as a refuge from predators is also likely to determine burrow architecture. The multiple 
entrances to burrow-systems observed at the muddier sites in the present study presumably provide access to shelter from predators. The casts of burrows made during the present study showed that burrows are interconnected and that, given their abundance within the sediment at some sites, it is unlikely that any particular section of this system is occupied exclusively by a single $\mathrm{crab}$. The existence of such a communal refuge from predation potentially allows individual crabs to search for food over larger areas of the sediment surface than if they were associated with a single burrow. Observations by Beer (1959) confirmed that, when threatened, $H$. crassa will retreat into the nearest available burrow, often sharing it with other individuals. He reported that for much of the time, however, individual crabs defend a particular opening and the area around it, and generally remain within ca $0.5 \mathrm{~m}$ of this opening.

For an intertidal species, burrows also provide protection from desiccation and extremes of temperature on the surface of the sediment. The burrows of Helice crassa are reported to extend down to the permanent water-table (Morton \& Miller 1968). Muddy sediments are likely to be less well drained than sandier ones and tend to retain water throughout the low-tide period (authors' pers. obs.) whereas in sandier sediments the height of the water table falls throughout the low-tide period (Drabsch et al. 1999). That burrow depth for $H$. crassa was found to be greater in the muddier sediments may reflect the fact that construction of deeper, more complex burrows is only possible in more cohesive sediments, rather than the need to burrow deeper to reach the water-table. A similar conclusion was reached by Takeda \& Kurihara (1987b) in their study of $H$. tridens in a Japanese saltmarsh, based on the observation that burrows were larger, deeper and more abundant in muddy relative to sandy substrata.

In summary, the results of the present study support the hypothesis that the abundance and complexity of the burrows of Helice crassa are greater in muddy substrata than in sandy ones. The impact of bioturbation by $H$. crassa on the topography and geochemistry of sediments will consequently also vary among different types of sediment. Among species of thalassinidean shrimps, total burrow volumes and total surface area of burrow wall per unit area of sediment typically ranged from 1000 to $11000 \mathrm{ml} \mathrm{m}^{-2}$ and $<1$ to $9 \mathrm{~m}^{2} \mathrm{~m}^{-2}$, respectively (see Table 5 of Griffis \& Suchanek 1991). In the present study, mean total volumes for $H$. crassa ranged from 1500 at $W B$ (sand) to $22000 \mathrm{ml} \mathrm{m}^{-2}$ at DC (mud) and values for total surface area ranged from 3.8 at WB to $13.6 \mathrm{~m}^{2} \mathrm{~m}^{-2}$ at DC (values are converted from those in Table 3). Griffis \& Chavez (1988) cited a value of $15 \%$ for the volume of burrow relative to the volume of the sediment for a thalassinidean. Equivalent values for $H$. crassa range from 2.4 to $14.0 \%$ (present study,
Table 3). These values suggest that the burrowing activity of $H$. crassa and its effect on sediment topography and geochemistry can be at least as great as that of thalassinideans. Burrowing by $H$. crassa and other crabs with similar burrowing habits (e.g. Helice spp., Uca spp.) represents a major factor in the ecology of estuarine sediments, including the fate of organic matter and anthropogenic contaminants.

Acknowledgements. We thank Sharon Nieukirk (Battelle) and Karen Burt, Jane Halliday, John Hawken, Corina Kemp, Lynette Steele, Lawrence Van Dam, Bob Wilcock and Erica Williams (NIWA) for help with field work and analyses of samples and data. Chris Hickey (NIWA) suggested the conductivity method for measuring surface area. Russell Cole (NIWA) provided helpful comments on an earlier draft. Funding for this study was provided by the Foundation for Research, Science and Technology of New Zealand. Funding support for T.H.DeW. was provided in part by the NIWA Visiting Scientist Programme

\section{LITERATURE CITED}

Aller RC (1978) Experimental studies of changes produced by deposit feeders on pore water sediment and overlying water chemistry. Am J Sci 278:1185-1234

Aller RC (1982) The effects of macrobenthos on chemical properties of marine sediment and overlying water. In: McCall PL, Tevesz MJS (eds) Animal-sediment relations. The biogenic alteration of sediments. Plenum Press, New York, p 53-102

Andersen $A \oslash$, Kristensen $E$ (1991) Effects of burrowing macrofauna on organic matter decomposition in coastal marine sediments. In: Meadows PS, Meadows A (eds) The environmental impact of burrowing animals and animal burrows. Clarendon Press, Oxford, p 201-204

Ankley GT, Di Toro DM, Hansen DJ, Berry WJ (1996) Technical basis and proposal for deriving sediment quality criteria for metals. Env Toxicol Chem 15:2056-2066

Beer CG (1959) Notes on the behaviour of two estuarine crab species. Trans Roy Soc NZ 86:197-203

Berner RA, Westrich JT (1985) Bioturbation and the early diagenesis of carbon and sulfur. Am J Sci 285:193-206

Bertness MD, Miller T (1984) The distribution and dynamics of Uca pugnax (Smith) burrows in a New England saltmarsh. J Exp Mar Biol Ecol 83:211-237

Buchanan JB (1984) Sediment analysis. In: Holme NA, MCIntyre $A D$ (eds) Methods for the study of marine benthos, 2nd edn. Blackwell Scientific Publications, Oxford, p 41-65

Davey JT (1994) The architecture of the burrows of Nereis diversicolor and its quantification in relation to sedimentwater exchange. J Exp Mar Biol Ecol 179:115-129

Davies-Colley RJ, Nelson PO, Williamson KJ (1985) Sulfide control of cadmium and copper concentrations in anaerobic estuarine sediments. Mar Chem 16:173-186

Drabsch J, Parnell KE, Hume TM, Dolphin TJ (1999) The capillary fringe and water table in an intertidal estuarine sand flat. Estuar Coast Shelf Sci 48:215-222

Emerson S, Jacobs L, Tebo B (1983) The behaviour of trace metals in marine anoxic waters: solubilities at the oxygenhydrogen sulfide interface. In: Wong CS, Boyle E, Bruland KW, Burton JD, Goldberg ED (eds) Trace metals in seawater. Plenum Press, New York, p 579-608 
Forster S, Graf G (1995) Impact of irrigation on oxygen flux into the sediment: intermittent pumping by Callianassa subterranea and 'piston-pumping' by Lanice conchilega. Mar Biol 123:335-346

Genoni GP (1991) Increased burrowing by fiddler crabs Uca rapax (Smith) (Decapoda Ocypodidae) in response to food supply. J Exp Mar Biol Ecol 147:267-285

Gilbert F, Bonin P, Stora G (1995) Effect of bioturbation on denitrification in a marine sediment from the west Mediterranean littoral. Hydrobiologia 304:49-58

Glasby GP, Stoffers P, Walter P, Davis KR, Renner RM (1988) Heavy metal pollution in Manukau and Waitemata Harbours, New Zealand. NZ J Mar Freshw Res 22: $595-611$

Golden Software Inc. (1995) SURFER ${ }^{3}$ for Windows version 6 user's guide. Golden Software Inc., Golden, CO

Griffis RB, Chavez FL (1988) Effects of sediment type on burrows of Callianassa californiensis Dana and C. gigas Dana. J Exp Mar Biol Ecol 117:239-253

Griffis RB, Suchanek TH (1991) A model of burrow architecture and trophic modes in thalassinidean shrimp (Decapoda: Thalassinidea). Mar Ecol Prog Ser 79: $171-183$

Hertweck G (1972) Georgia coastal region Sapelo Island USA sedimentology and biology. V. Distribution and environmental significance of lebensspuren and in situ skeletal remains. Senckenberg Marit 4:125-167

Jones MB (1976) Limiting factors in the distribution of intertidal crabs (Crustacea Decapoda) in the AvonHeathcote Estuary, Christchurch. NZ J Mar Freshw Res $10: 577-587$

Jones MB (1980) Reproductive ecology of the estuarine burrowing mud crab Helice crassa (Grapsidae). Estuar Coast Mar Sci 11:433-443

Jones MB, Simons MJ (1982) Habitat preferences of two estuarine burrowing crabs Helice crassa Dana (Grapsidae) and Macrophthalmus hirtipes (Jacquinot) (Ocypodidae). J Exp Mar Biol Ecol 56:49-62

Jones MB, Simons MJ (1983) Latitudinal variation in reproductive characteristics of a mud crab Helice crassa (Grapsidae). Bull Mar Sci 33:656-670

Katz LC (1980) Effects of burrowing by the fiddler crab UCa pugnax (Smith). Estuar Coast Mar Sci 11:233-237

Knox GA (1986) Estuarine ecosystems: a systems approach, Vol 1. CRC, Boca Raton, FL

Lyons WB, Fitzgerald WF (1983) Trace metals speciation in nearshore anoxic and suboxic pore waters. In: Wong CS, Boyle E, Bruland KW, Burton JD, Goldberg ED (eds) Trace metals in seawater. Plenum Press, New York, p 621-641

Mayer MS, Schaffner L, Kemp WM (1995) Nitrification potentials of benthic macrofaunal tubes and burrow walls effects of sediment $\mathrm{NH}_{4}{ }^{+}$and animal irrigation behavior. Mar Ecol Prog Ser 121:157-169

Mclay CL (1988) Brachyura and crab-like anomura of New Zealand. University of Auckland, Leigh Marine Laboratory, Auckland

Meadows PS, Meadows A. (1991) The geotechnical and geochemical implications of bioturbation in marine sedimentary ecosystems. In: Meadows PS, Meadows A (eds) The

Editorial responsibility: Otto Kinne (Editor), Oldendorf/Luhe, Germany environmental impact of burrowing animals and animal burrows. Clarendon Press, Oxford p 157-181

Meadows PS, Tait J (1989) Modification of sediment perme ability and shear strength by two burrowing invertebrates Mar Biol 101:75-82

Montague CL (1981) The influence of some larger animals on subsurface metabolic processes in intertidal sediments Estuaries 4:289

Morrisey DJ (1987) Effect of population density and presence of a potential competitor on the growth rate of the mud snail Hydrobia ulvae (Pennant). J Exp Mar Biol Ecol 108: $275-295$

Morse JW (1994) Interactions of trace metals with authogenic sufide minerals: implications for their bioavailability. Mar Chem 46:1-6

Morton J, Miller M (1968) The New Zealand sea shore Collins, Auckland

Nickell LA, Atkinson RJA (1995) Functional morphology of burrows and trophic modes of three thalassinidean shrimp species, and a new approach to the classification of thalassinidean burrow morphology, Mar Ecol Prog Ser 128 181-197

Nye PA (1977) Reproduction, growth and distribution of the grapsid crab Helice crassa (Dana 1851) in the southern part of New Zealand. Crustaceana 33:75-89

Pelegrí SP, Blackburn TH (1994) Bioturbation effects of the amphipod Corophium volutator on microbial nitrogen transformations in marine sediments. Mar Biol 121: 253-258

Peterson GS, Ankley GT, Leonard EN (1996) Effects of bioturbation on metal sulfide oxidation in surficial freshwater sediments. Environ Toxicol Chem 15:2147-2155

Rhoads DC, Boyer LF (1982) The effects of marine benthos on physical properties of sediments: a successional perspective. In: McCall PL, Tevesz MJS (eds) Animal-sediment relations. The biogenic alteration of sediments. Plenum Press, New York, p 3-52

Ridd PV (1996) Flow through animal burrows in mangrove creeks. Estuar Coast Shelf Sci 43:617-625

Takeda S, Kurihara Y (1987a) The effects of burrowing of Helice tridens (De Haan) on the soil of a salt-marsh habitat. J Exp Mar Biol Ecol 113:79-89

Takeda S, Kurihara Y (1987b) The distribution and abundance of Helice tridens (De Haan) burrows and substratum conditions in a northeastern Japan saltmarsh (Crustacea Brachyura). J Exp Mar Biol Ecol 107:9-19

Williamson RB, Hume TM, Mol-Krijnen J (1994) A comparison of the early diagenetic environment in intertidal sands and muds of the Manukau Harbour, New Zealand. Environ Geol 24:254-266

Williamson RB, Wilcock RJ, Wise BE, Pickmere SE (in press) The effect of burrowing by the crab Helice crassa on the chemistry of intertidal muddy sediments. Env Toxicol Chem

Wolfrath B (1992) Burrowing of the fiddler crab Uca tangeri in the Ria Formosa in Portugal and its influence on sediment structure. Mar Ecol Prog Ser 85:237-243

Zar JH (1984) Biostatistical design, 2nd edn. Prentice Hall, Englewood Cliffs, NJ

Submitted: August 18, 1998; Accepted: February 4, 1999

Proofs received from author(s): May 14, 1999 